\title{
A rare congenital anemia is caused by mutations in the centralspindlin complex
}

Sandeep N. Wontakal ${ }^{1,5 *}$, Mishan Britto ${ }^{3 *}$, Sarah Tannenbaum², Benjamin H.

Durham $^{1,4}$, Margaret T. Lee ${ }^{2}$, Masanori Mishima ${ }^{3,5}$

*: co-first authors

1: Department of Pathology and Cell Biology

2: Department of Pediatrics, Columbia University Irving Medical Center, Columbia

University, New York, NY 10032 USA

10 3: Centre for Mechanochemical Cell Biology \& Division of Biomedical Sciences,

11 Warwick Medical School, University of Warwick, Coventry CV4 7AL, UK.

12 4: Department of Pathology, Memorial Sloan Kettering Cancer Center, New York, NY

1310065

14 5: Corresponding authors: Sandeep N. Wontakal

Department of Pathology and Cell Biology

Columbia University Irving Medical Center

New York, NY 10032

Phone: 212-342-4467

email: sw2869@cumc.columbia.edu

Masanori Mishima

Division of Biomedical Sciences

Warwick Medical School

University of Warwick

Coventry CV4 7AL, UK

Phone: +44 (0) 2476151928

email:m.mishima@warwick.ac.uk

Conflict of interest statement: The authors do not have any conflict of interest to declare. 
medRxiv preprint doi: https://doi.org/10.1101/2021.04.07.21254990; this version posted April 10, 2021. The copyright holder for this preprint (which was not certified by peer review) is the author/funder, who has granted medRxiv a license to display the preprint in perpetuity. It is made available under a CC-BY-NC-ND 4.0 International license .

\section{Abstract}

31 Congenital dyserythropoietic anemias (CDAs) are rare disorders characterized by

32 morphologic abnormalities of erythroid precursors leading to ineffective erythropoiesis.

33 CDA type III (CDAIII), characterized by erythroblast multinucleation, represents the rarest

34 form with only $\sim 60$ patients described in the literature. Previous work, studying two

35 independent families, identified a causative dominant missense mutation in KIF23, which

36 encodes for the kinesin MKLP1. Here, we describe a sporadic CDAlll case associated

37 with compound heterozygous variants in RACGAP1, a gene not previously associated

38 with any disease. RACGAP1 encodes CYK4, a GTPase activating protein (GAP) for Rho-

39 family GTPases, which interacts with MKLP1 to form the centralspindlin complex.

40 Functional assays show these RACGAP1 variants cause cytokinesis defects due, at least

41 in part, to altering the substrate specificities of the GAP activity of CYK4. These findings

42 provide novel insights into the structural determinants of the GAP activity and

43 demonstrates that cytokinesis failure due to centralspindlin defects leads to CDAIII. Our

44 findings highlight the importance of viewing diseases as malfunctions of common

45 biological pathways/complexes and suggests that next-generation sequencing analysis

46 pipelines should integrate a systems approach in order to identify such functionally related

47 variants. 
medRxiv preprint doi: https://doi.org/10.1101/2021.04.07.21254990; this version posted April 10, 2021. The copyright holder for this preprint (which was not certified by peer review) is the author/funder, who has granted medRxiv a license to display the preprint in perpetuity.

\section{Introduction}

49 Congenital dyserythropoietic anemias (CDAs) are a heterogenous group of rare inherited

50 disorders characterized by ineffective erythropoiesis leading to anemia. CDAs were

51 classically distinguished into three major types based on erythroblast morphology in the

52 bone marrow; a fourth type emerged that encompassing atypical morphologies $(1,2)$. The

53 genetic etiology of these disorders include mutations in CDAN1 or C15ORF41 for CDAI

$54(3,4), \operatorname{SEC} 23 B$ for CDAII $(5,6), K I F 23$ for CDAIII $(7)$, and KLF1, GATA1, ALAS2, or

55 VPS4A for some of the CDA variants (8-11). CDAlll is the rarest form with $\sim 60$ patients

56 described.

58 The characteristic abnormality seen in CDAIII is multinucleated erythroblasts that are reminiscent of cells undergoing endoreplication (i.e., DNA replication without cell division).

60 Studies of two independent CDAIII families identified a dominant missense mutation in

61 KIF23 (c.2747C>G; p.P916R) that segregated with disease (7). KIF23 encodes MKLP1,

62 the kinesin subunit of centralspindlin, which is essential for proper cytokinesis (12).

63 Functional studies of the p.P916R mutation demonstrated failure of proper cytokinesis

64 resulting in multinucleated cells, the hallmark of CDAIII (7).

66 The original CDAIII families showed an autosomal dominant inheritance pattern (13-15).

67 However, a few sporadic cases were reported with variability in clinical presentation that

68 seem to have an autosomal recessive pattern of inheritance, suggesting genetic

69 heterogeneity $(1,2)$. To date, no genetic cause has been identified in such autosomal

70 recessive cases. Here, we report a sporadic case of CDAllI with compound heterozygous 
medRxiv preprint doi: https://doi.org/10.1101/2021.04.07.21254990; this version posted April 10, 2021. The copyright holder for this preprint (which was not certified by peer review) is the author/funder, who has granted medRxiv a license to display the preprint in perpetuity. It is made available under a CC-BY-NC-ND 4.0 International license.

71 variants in RACGAP1, which encodes CYK4/MgcRacGAP, the other component of the 72 centralspindlin complex. 
medRxiv preprint doi: https://doi.org/10.1101/2021.04.07.21254990; this version posted April 10, 2021. The copyright holder for this preprint (which was not certified by peer review) is the author/funder, who has granted medRxiv a license to display the preprint in perpetuity.

\section{Results and Discussion}

74 The proband initially presented as a toddler with unexplained macrocytic anemia that has

75 persisted throughout his life, but was never severe enough to require a transfusion

76 (Supplemental Fig. 1A). Initial testing ruled out common causes of macrocytic anemia

77 including vitamin B12-deficiency, folate-deficiency, and hypothyroidism (data not shown).

78 Red blood cell (RBC) adenosine deaminase activity (ADA), which can be elevated in

79 patients with Diamond-Blackfan anemia (DBA), was also found to be normal (data not

80 shown). A bone marrow biopsy was performed, which showed striking dyserythropoiesis

81 with megaloblastoid changes accompanied by multi-nucleated erythroid precursors and

82 characteristic gigantoblasts (Fig. 1A), thereby establishing the diagnosis of CDAlll. To

83 determine the underlying genetic cause of this patient's CDAIII, whole exome sequencing

84 (WES) was performed as part of his clinical care. The previously reported p.P916R variant

85 in KIF23 (7) was not seen in the proband, nor were any other putative causative variants

86 in KIF23 (data not shown). However, the proband did have compound heterozygous

87 variants in RACGAP1, namely, c.1187T>A; p.L396Q (inherited from parent 1) and

88 c.1294C>T; p.P432S (inherited from parent 2) (Fig. 1B). Complete blood counts were

89 performed on the parents, and neither was anemic (Supplemental Fig. 1B), suggesting

90 that these alleles are recessive. Neither variant was seen in the genome aggregation

91 database (gnomAD) (16), indicating that both variants are extremely rare. In addition,

92 both residues are highly conserved through evolution (Fig. 1C) with each alteration

93 resulting in non-conservative amino acid substitutions. Indeed, both variants have a

94 combined annotation dependent depletion (CADD) score of $>25$ and both are predicted

95 to be deleterious by several other in silico algorithms including Provean, PolyPhen, SIFT, 
medRxiv preprint doi: https://doi.org/10.1101/2021.04.07.21254990; this version posted April 10, 2021. The copyright holder for this preprint (which was not certified by peer review) is the author/funder, who has granted medRxiv a license to display the preprint in perpetuity.

It is made available under a CC-BY-NC-ND 4.0 International license .

96 and Mutation Taster. These results suggested that the compound heterozygous variants

97 in RACGAP1 variant identified in this patient may be the first known genetic cause of an

98 autosomal recessive form of CDAlll.

99

100 To test the functional consequences of these variants, an RNAi-mediated depletion and

101 rescue assay was performed, which is similar to the experiments that established the

102 pathogenicity of p.P916R in KIF23 (7). At least two independent, stable, HeLa cell lines

103 were generated expressing an RNAi-resistant full-length CYK4-GFP construct (17)

104 containing the wild-type (WT) sequence, the p.L396Q variant, or the p.P432S variant,

105 along with a GFP only control (Fig. 2). Consistent with the findings in this family, we were

106 able to generate stable lines from both variants, indicating that they do not have a strong

107 dominant effect. Immunoblotting revealed that expression levels of the CYK4-GFP

108 transgenes varied between stable lines (Fig. 2A and B) but were comparable to the

109 endogenous protein (Supplementary Figure 2). These cells were then subjected to RNAi

110 to deplete endogenous protein levels and live imaging was performed to determine the

111 effect of each construct on cytokinesis. Cells expressing GFP alone showed a high

112 frequency of cytokinesis failure, resulting in multinucleated cells, whereas this effect was

113 strongly suppressed in cells expressing WT CYK4-GFP (Fig. 2C). Of note, there was a

114 correlation between WT CYK4-GFP levels, which was monitored by GFP fluorescence,

115 and the ability to rescue the cytokinesis defect; this allowed us to establish an expression

116 threshold where WT CYK4-GFP was able to rescue the cytokinesis defect (Fig. 2B).

117 Using this threshold, we find the p.L396Q variant had a modest, but significant, defect in

118 rescuing the phenotype (Fig. 2B and C). One stable line with high expression of this 
medRxiv preprint doi: https://doi.org/10.1101/2021.04.07.21254990; this version posted April 10, 2021. The copyright holder for this preprint (which was not certified by peer review) is the author/funder, who has granted medRxiv a license to display the preprint in perpetuity. It is made available under a CC-BY-NC-ND 4.0 International license .

119 variant (L15 - see Fig. 2A and B) showed a modest inability to rescue cytokinesis, 120 whereas the other stable line (L6) showed a stronger deficit in rescuing the cytokinesis

121 failure (Fig. 2B and C). Strikingly, the p.P432S variant almost completely failed to rescue

122 the depletion of the endogenous CYK4 in all three independent lines, regardless of the 123 transgene expression (Fig. 2B and C). Thus, both variants negatively affect the ability of 124 CYK4 to promote proper cytokinesis.

126 We next sought to understand the mechanism by which these variants led to defective 127 cytokinesis. A GAP domain stimulates the GTP hydrolysis by a GTPase, such as RhoA, 128 Cdc42, or Rac1, using a conserved arginine residue (the so called "arginine finger," R385 129 in CYK4) (18-20). This facilitates the conversion of the target GTPase from the GTP130 bound to the GDP-bound form, which typically results in switching off their downstream 131 effectors (21). The GAP domain of CYK4 stimulates Cdc42 and Rac1 with much greater 132 efficiency than RhoA (22-25). The structural basis for this specificity is unclear since most 133 amino acid residues on the GAP-binding surface of the Rho-family GTPases are 134 conserved among these members (Fig. 3A, light pink). Only three residues closely located 135 to each other near the periphery of the binding surface are substrate-specific (i.e., D90, 136 E97, and M134 in RhoA; S88, E95, N132 in Cdc42, Fig. 3A) (29, 31) and evolutionarily 137 conserved (Supplementary Figure S3). The counterparts in CYK4 are found on a 138 structural motif consisting of two helixes linked by a loop (Fig. 3A, cyan) between R385 139 (blue) and P432 (magenta), which also includes L396 (green). Thus, we investigated 140 whether these new CDAlll variants might affect the GAP activity of CYK4 towards RhoA, 141 Rac1, and Cdc42. 
medRxiv preprint doi: https://doi.org/10.1101/2021.04.07.21254990; this version posted April 10, 2021. The copyright holder for this preprint (which was not certified by peer review) is the author/funder, who has granted medRxiv a license to display the preprint in perpetuity.

143 GTP hydrolysis by RhoA, Rac1, or Cdc42 was monitored by measuring the released free

144 phosphate using an enzyme coupled photometric assay under a multiple turnover

145 condition in which the GDP release is not rate-limiting $(26,27)$. The GAP activity was

146 determined as the increase of the GTPase rate in the presence of the CYK4 GAP domain

147 (Fig. 1C). As a negative control, we included a mutant for the 'arginine finger' (p.R385A)

$148(24,28)$. As expected, WT CYK4 showed significantly stronger ability to stimulate the

149 GTPase activities of Cdc42 and Rac1, as compared to that of RhoA (Fig. 3B). As 150 expected, the p.R385A negative control severely diminished all the GTPase activities,

151 almost to the basal level. Interestingly, the p.P432S variant showed no effect on

152 stimulation of Cdc42 and Rac1, but significantly elevated the ability to stimulate RhoA

153 (Fig. 3A). In contrast, the p.L396Q variant showed no difference in stimulating RhoA

154 activity, but caused a significant decrease in the ability to stimulate Cdc42 and Rac1

155 activity (Fig. 3B). These results suggest that both variants differentially modify the

156 substrate specificity of the CYK4 GAP domain.

158 As centralspindlin is a key signaling hub for cytokinesis $(29,30)$, we also tested whether

159 the variants affected CYK4 localization during cell division. WT-CYK4 showed diffuse

160 cytoplasmic localization during metaphase but began to accumulate at the spindle

161 midzone at the onset of anaphase (Fig. 4A, white arrows), as previously reported (12, 17,

162 24, 31-33). The p.L396Q variant showed a similar pattern of localization (Fig. 4B). In

163 contrast, the p.P432S variant failed to accumulate sharply at the spindle midzone, but

164 instead localized to the equatorial cell cortex with a ring-like pattern (Fig. 4C, magenta 
medRxiv preprint doi: https://doi.org/10.1101/2021.04.07.21254990; this version posted April 10, 2021. The copyright holder for this preprint (which was not certified by peer review) is the author/funder, who has granted medRxiv a license to display the preprint in perpetuity. It is made available under a CC-BY-NC-ND 4.0 International license .

165 arrows). This abnormal localization was often accompanied by a failure to form a 166 cleavage furrow or by formation of a transient shallow furrow that failed to complete (Fig. $1674 \mathrm{C})$. Taken together, these results demonstrate that the severe cytokinesis defect of the p.P432S variant (Fig. 2B and C) is likely due to the elevated GAP activity towards RhoA

169 (Fig. 3B) and severe mislocalization (Fig 4B), whereas the modest cytokinesis defect of 170 the p.L396Q variant (Fig. 2B\&C) is primarily due to the diminished GAP activity towards 171 Rac and Cdc42 (Fig. 2B). Most reported CDAIII cases derive from studies of two families with a dominant missense

174 mutation in KIF23 (7). However, reports of sporadic cases suggested the existence of 175 autosomal recessive form(s) with unknown genetic etiology $(1,2,34,35)$. Here we report 176 a novel sporadic case of CDAlll and identify compound heterozygous variants in 177 RACGAP1 (Fig. 1), which forms the centralspindlin complex with KIF23. Severe loss-of178 function (LoF) variants in RACGAP1 are very common within gnomAD (as indicated by a 179 probability of LoF intolerant ( $\mathrm{pLI}$ ) score of 0), whereas such LoF variants are rarely seen 180 in KIF23 (pLI score of 1) (16). This suggests that strong LoF variants in RACGAP1 are 181 likely to be recessive, whereas such variants would be dominant in KIF23 due to 182 haploinsufficiency. Neither of the two RACGAP1 variants in the proband showed strong 183 dominant negative effects, but both result in defects in cytokinesis in the absence of the 184 wild-type protein (Fig. 2). This is at least partially due to altered GAP activity of both 185 variants (Fig. 3) along with mislocalization of the p.P432S variant (Fig. 4). 
medRxiv preprint doi: https://doi.org/10.1101/2021.04.07.21254990; this version posted April 10, 2021. The copyright holder for this preprint (which was not certified by peer review) is the author/funder, who has granted medRxiv a license to display the preprint in perpetuity. It is made available under a CC-BY-NC-ND 4.0 International license .

187 The role of the GAP domain in CYK4 has long been an enigma (36-38). Our findings

188 demonstrate the importance of proper substrate specificity of the CYK4 GAP domain for

189 successful cytokinesis. The cortical mislocalization of the p.P432S variant (Fig. 4), which

190 exhibits an elevated GAP activity against RhoA but not to Rac1 or Cdc42 (Fig.3), indicates

191 the importance of the proper target specificity of the GAP domain for the subcellular

192 localization of centralspindlin. This implies a novel mechanism for the cortical recruitment

193 of centralspindlin via the RhoA-GAP interaction, which is hidden during the normal cell

194 division, but might contribute to the cleavage signalling when the central spindle is 195 disrupted $(39,40)$. We propose a model based on the GAP activity that tries to explain

196 the recessive nature of the identified variants (Fig. 4B).

An important question that still remains is why dysfunction of the centralspindlin complex,

199 which is broadly expressed, leads to a predominately RBC-restricted phenotype. This is

200 reminiscent of the ribosomal protein gene mutations associated with DBA, which is

201 another form of congenital macrocytic anemia. Similar to DBA (41), CDAlll may serve as

202 an additional model to understand how cell-type restricted phenotypes arise from broadly

203 expressed genes.

205 In conclusion, our findings strongly suggest that CDAlll is a disease of abnormal 206 centralspindlin complex function. Mutations in other proteins that interact and function 207 with centralspindlin (42) may also lead to a similar phenotypes in humans. Indeed, 208 viewing diseases as aberrancies of genetic pathways versus defects in individual genes 209 may provide the proper framework on which to build a taxonomical structure of disease. 
medRxiv preprint doi: https://doi.org/10.1101/2021.04.07.21254990; this version posted April 10, 2021. The copyright holder for this preprint (which was not certified by peer review) is the author/funder, who has granted medRxiv a license to display the preprint in perpetuity. It is made available under a CC-BY-NC-ND 4.0 International license.

\section{Methods}

211 See supplemental methods for more detailed information.

212 Study approval: The Columbia University Irving Medical Center (CUIMC) IRB panel

213 deemed this study exempt from IRB approval because it was considered a case study. 
medRxiv preprint doi: https://doi.org/10.1101/2021.04.07.21254990; this version posted April 10, 2021. The copyright holder for this preprint (which was not certified by peer review) is the author/funder, who has granted medRxiv a license to display the preprint in perpetuity. It is made available under a CC-BY-NC-ND 4.0 International license.

\section{Author contributions}

215 SNW - acquiring data, analyzing data, providing reagents, and writing the manuscript

$216 \mathrm{MB}-$ conducting experiments, acquiring data, analyzing data, providing reagents

217 ST, BHD, ML - acquiring data

$218 \mathrm{MM}$ - designing research studies, analyzing data, and writing the manuscript 
medRxiv preprint doi: https://doi.org/10.1101/2021.04.07.21254990; this version posted April 10, 2021. The copyright holder for this preprint (which was not certified by peer review) is the author/funder, who has granted medRxiv a license to display the preprint in perpetuity. It is made available under a CC-BY-NC-ND 4.0 International license .

\section{Acknowledgments}

220 We thank the patient and his parents for their cooperation throughout the studies. We

221 thank Drs. Sergey Lekomtsev and Mark Petronczki for plasmids, and Drs. Vimla Aggarwal,

222 Julie Canman, Kartik Ganapathi, Kazutaka Murayama, Mikako Shirouzu, Steve Spitalnik,

223 and Jenny Yang for helpful discussions and/or critical comments on the manuscript. This

224 work was supported by 1K08NS119567 to SNW and a Cancer Research UK program

225 grant (C19769/ A11985) to MM. 


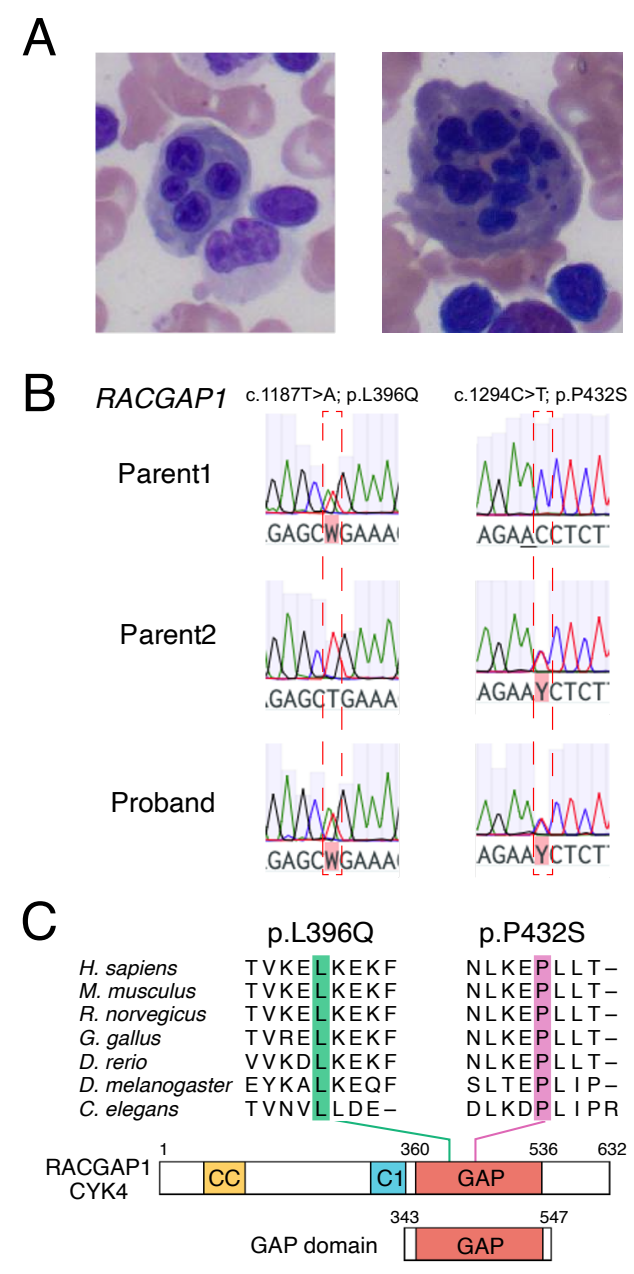

227 Figure 1: Identification of a patient with CDAlll that has compound heterozygous variants in

\section{RACGAP1}

229 A) A bone marrow aspirate from the proband showing a characteristic multi-nucleated erythroblast (left) 230 and a gigantoblast (right).

231 B) Electropherograms for the Parent 1 (top), Parent 2 (middle), and the proband (bottom) for variants

232 c.1187T>A (left panels) and c.1294C>T (right panels).

233 C) Domain structure of CYK4 showing the coiled-coil (CC), C1, and RhoGAP (GAP) domains with the 234 MKLP1-interacting region. Sequence alignment of CYK4 orthologs showing the strong conservation of 235 indicated residues. The GAP domain fragment (aa $343-547$ ) was used for the biochemical assays in 236 Fig. 3. 


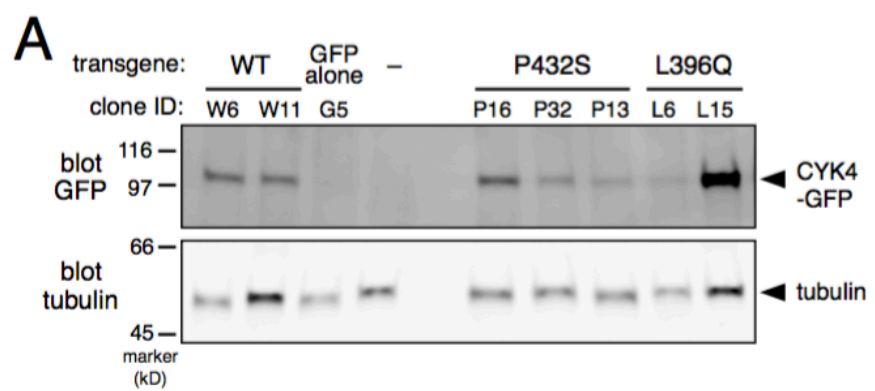

B

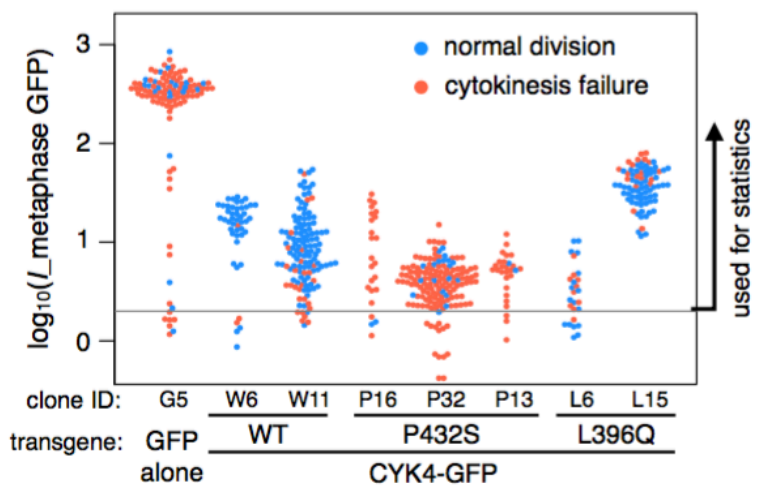

C

239 Figure 2: CYK4 variants result in cytokinesis failure

240 A) Monoclonal HeLa Kyoto cell lines stably transformed with RACGAP1 cDNA constructs or a control GFP construct were generated and assessed for the expression of CYK4-GFP by immunoblotting mitotic lysates with an anti-GFP antibody (blot GFP). The parental HeLa Kyoto cells ("-") serve as a negative control. The same membrane was blotted for tubulin as a loading control (blot tubulin).

244 B) The expression level of CYK4-GFP was monitored by the GFP signal during metaphase after siRNAmediated depletion of the endogenous CYK4. The mean intensity above the background signal of individual cells was plotted on a log scale (dots) with the success or failure of cytokinesis by color.

247 C) The frequencies of cytokinesis failure calculated from the indicated number of cytokinesis failure among

248 the observed cells in at least three independent experiments per line are shown with the $95 \%$ confidence interval. The $p$-values $\left.{ }^{* * *}, p<0.001 ;{ }^{* *}, p<0.01 ;{ }^{*}, p<0.05\right)$ of the statistical test for the difference from the WT cell line (w6) were corrected for multiple comparisons (Dunnett). 

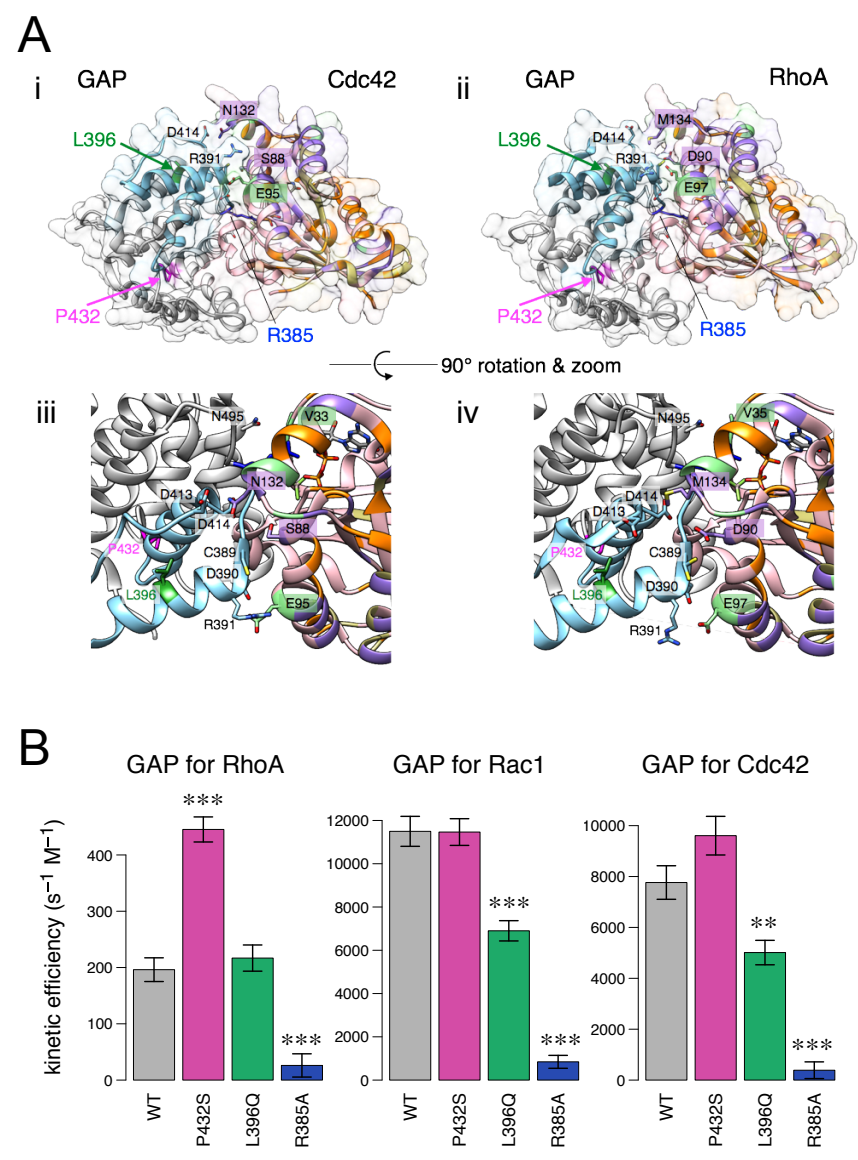

Figure 3: CYK4 variants result in altered GAP activities towards RhoA, Rac1, and Cdc42

253 A) Crystal structures of the CYK4 GAP domain (left) in a complex with Cdc42 (i and iii, PDB:5C2J) or with

254 RhoA (ii and iv, PDB:5C2K) (right). The residues of the GTPases are color-coded for the difference between

255 the subtypes of Rho GTPases (canonical Rho, Rac, and Cdc42): pink, conserved among the three

256 subtypes; orange, Rho-specific (i.e., identical between Rac and Cdc42); green, Rac-specific; khaki, Cdc42-

257 sepcific; purple, different in all the three. The arginine finger (R385) and the residues found to be mutated 258 in this study (L396 and P432) on the GAP are marked in blue, green and magenta, respectively. The region 259 between R385 (blue) and P432 (cyan) makes contact with the three subtype-specific residues on the 260 GTPases (S88, E95, and N132 on CDC42 and D90, E97, and M134 on RhoA.

261 B) The GAP activity, i.e., the stimulation of GTPase of human RhoA, Cdc42 and Rac, by the CYK4 GAP 262 domain with or without mutations (WT, p.P432S, p.L396Q, p.R385A). The kinetic efficiency $\left(k_{\mathrm{cat}} / K_{\mathrm{M}}\right)$ was 263 estimated with a linear model between the rate of GAP-stimulated GTPase activity versus the concentration 264 of the GTPase (Supplementary Figure 4) and shown with the standard error. The $p$-values (***, $p<0.001$; $265 * *, p<0.01$ ) of the statistical test for the difference from the control (WT GAP) were corrected for multiple 266 comparisons (Dunnett). 
medRxiv preprint doi: https://doi.org/10.1101/2021.04.07.21254990; this version posted April 10, 2021. The copyright holder for this preprint (which was not certified by peer review) is the author/funder, who has granted medRxiv a license to display the preprint in perpetuity.

It is made available under a CC-BY-NC-ND 4.0 International license .
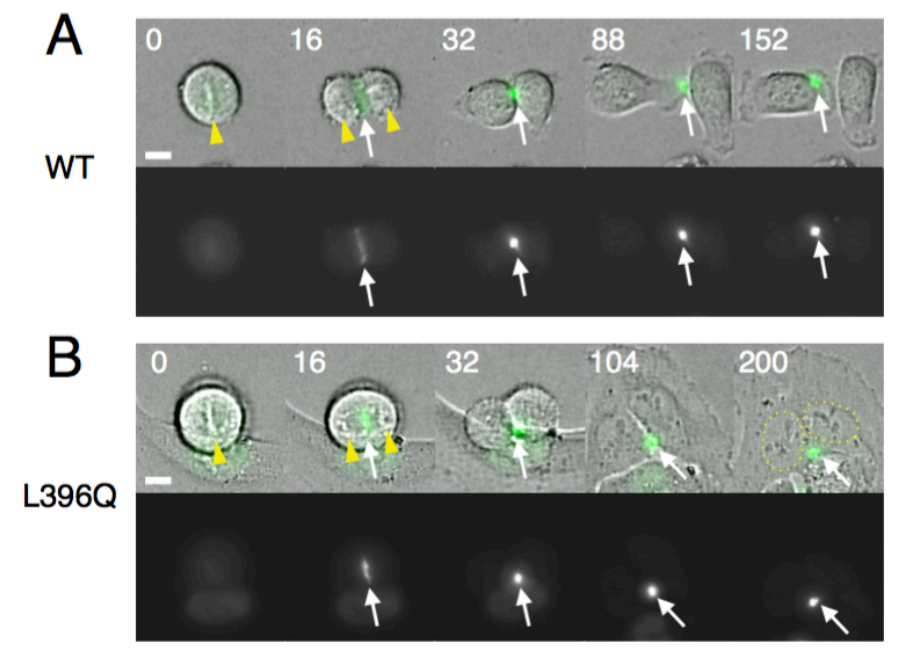

\section{Figure 4: CYK4 variants cause distinct cytokinesis phenotypes}

269 A-C) Stills from live microscopy of cells stably expressing the wildtype (WT) or a variant CYK4 tagged with 270 GFP after depletion of the endogenous protein (top, bright field and GFP in green; bottom, GFP in 271 grayscale). The transition from metaphase to anaphase was monitored by chromosomes (yellow 272 arrowheads). White arrows indicate the localization of each of the indicated constructs.

273 D) Proposed model for the significance of target preference of the GAP domain of CYK4 in cytokinesis. The 274 elevated activity of p.P432S on RhoA in combination with the reduced activity on Rac/Cdc42 by the 275 p.L396Q variant disturbs the proper balance between these Rho GTPases important for cytokinesis. 
medRxiv preprint doi: https://doi.org/10.1101/2021.04.07.21254990; this version posted April 10, 2021. The copyright holder for this preprint (which was not certified by peer review) is the author/funder, who has granted medRxiv a license to display the preprint in perpetuity. It is made available under a CC-BY-NC-ND 4.0 International license .

\section{References}

1. Iolascon A, Heimpel H, Wahlin A, Tamary H. Congenital dyserythropoietic anemias: molecular insights and diagnostic approach.. Blood 2013;122(13):2162-2166.

2. Gambale A, lolascon A, Andolfo I, Russo R. Diagnosis and management of congenital dyserythropoietic anemias.. Expert Rev Hematol 2016;9(3):283-296.

3. Dgany $\mathrm{O}$ et al. Congenital dyserythropoietic anemia type $\mathrm{I}$ is caused by mutations in codanin-1.. Am. J. Hum. Genet. 2002;71(6):1467-1474.

4. Babbs $\mathrm{C}$ et al. Homozygous mutations in a predicted endonuclease are a novel cause of congenital dyserythropoietic anemia type I.. Haematologica 2013;98(9):13831387.

5. Schwarz $\mathrm{K}$ et al. Mutations affecting the secretory COPII coat component SEC23B cause congenital dyserythropoietic anemia type II.. Nat. Genet. 2009;41(8):936-940. 6. Bianchi $P$ et al. Congenital dyserythropoietic anemia type II (CDAll) is caused by mutations in the SEC23B gene.. Hum. Mutat. 2009;30(9):1292-1298.

7. Liljeholm M et al. Congenital dyserythropoietic anemia type III (CDA III) is caused by a mutation in kinesin family member, KIF23.. Blood 2013;121(23):4791-4799.

8. Arnaud $L$ et al. A dominant mutation in the gene encoding the erythroid transcription factor KLF1 causes a congenital dyserythropoietic anemia.. Am. J. Hum. Genet. 2010;87(5):721-727.

9. Nichols KE et al. Familial dyserythropoietic anaemia and thrombocytopenia due to an inherited mutation in GATA1.. Nat. Genet. 2000;24(3):266-270.

10. Sankaran VG et al. X-linked macrocytic dyserythropoietic anemia in females with an ALAS2 mutation. J. Clin. Invest. 2015;

11. Seu KG et al. VPS4A mutations in humans cause syndromic congenital dyserythropoietic anemia due to cytokinesis and trafficking defects.. Am. J. Hum. Genet. 2020;107(6):1149-1156.

12. Mishima M, Kaitna S, Glotzer M. Central spindle assembly and cytokinesis require a kinesin-like protein/RhoGAP complex with microtubule bundling activity.. Dev. Cell 2002;2(1):41-54.

13. Wolff JA, Von Hofe FH. Familial erythroid multinuclearity.. Blood 1951;6(12):12741283.

14. Bergstrom I, Jacobsson L. Hereditary benign erythroreticulosis.. Blood 1962;19:296-303.

15. Accame EA, de Tezanos Pinto M. [Congenital dyserythropoiesis with erythroblastic polyploidy. Report of a variety found in Argentinian Mesopotamia (author's transl)].. Sangre (Barc.) 1981;26(5-A):545-555.

16. Karczewski $\mathrm{KJ}$ et al. The mutational constraint spectrum quantified from variation in 141,456 humans.. Nature 2020;581(7809):434-443.

17. Lekomtsev $S$ et al. Centralspindlin links the mitotic spindle to the plasma membrane during cytokinesis.. Nature 2012;492(7428):276-279.

18. Nassar N, Hoffman GR, Manor D, Clardy JC, Cerione RA. Structures of Cdc42 bound to the active and catalytically compromised forms of Cdc42GAP.. Nat. Struct. Biol. 1998;5(12):1047-1052.

19. Rittinger $\mathrm{K}$ et al. Crystal structure of a small $\mathrm{G}$ protein in complex with the GTPaseactivating protein rhoGAP.. Nature 1997;388(6643):693-697.

20. Rittinger K, Walker PA, Eccleston JF, Smerdon SJ, Gamblin SJ. Structure at 1.65 A 
medRxiv preprint doi: https://doi.org/10.1101/2021.04.07.21254990; this version posted April 10, 2021. The copyright holder for this preprint (which was not certified by peer review) is the author/funder, who has granted medRxiv a license to display the preprint in perpetuity. It is made available under a CC-BY-NC-ND 4.0 International license .

of RhoA and its GTPase-activating protein in complex with a transition-state analogue.. Nature 1997;389(6652):758-762.

21. Tcherkezian J, Lamarche-Vane N. Current knowledge of the large RhoGAP family of proteins.. Biol. Cell 2007;99(2):67-86.

22. Jantsch-Plunger $V$ et al. CYK-4: A Rho family gtpase activating protein (GAP) required for central spindle formation and cytokinesis.. J. Cell Biol. 2000;149(7):13911404.

23. Touré A et al. MgcRacGAP, a new human GTPase-activating protein for Rac and Cdc42 similar to Drosophila rotundRacGAP gene product, is expressed in male germ cells.. J. Biol. Chem. 1998;273(11):6019-6023.

24. Bastos RN, Penate X, Bates M, Hammond D, Barr FA. CYK4 inhibits Rac1dependent PAK1 and ARHGEF7 effector pathways during cytokinesis.. J. Cell Biol. 2012;198(5):865-880.

25. Amin E et al. Deciphering the molecular and functional basis of RHOGAP family proteins: A SYSTEMATIC APPROACH TOWARD SELECTIVE INACTIVATION OF RHO FAMILY PROTEINS.. J. Biol. Chem. 2016;291(39):20353-20371.

26. Zhang B, Wang ZX, Zheng Y. Characterization of the interactions between the small GTPase Cdc42 and its GTPase-activating proteins and putative effectors. Comparison of kinetic properties of Cdc42 binding to the Cdc42-interactive domains.. J. Biol. Chem. 1997;272(35):21999-22007.

27. Bao H et al. Structural Basis for the Specific Recognition of RhoA by the Dual GTPase-activating Protein ARAP3.. J. Biol. Chem. 2016;291(32):16709-16719. 28. Kawashima T et al. MgcRacGAP is involved in the control of growth and differentiation of hematopoietic cells.. Blood 2000;96(6):2116-2124.

29. Mishima M. Centralspindlin in Rappaport's cleavage signaling.. Semin. Cell Dev. Biol. 2016;53:45-56.

30. D'Avino PP, Giansanti MG, Petronczki M. Cytokinesis in animal cells.. Cold Spring Harb. Perspect. Biol. 2015;7(4):a015834.

31. Hirose K, Kawashima T, Iwamoto I, Nosaka T, Kitamura T. MgcRacGAP is involved in cytokinesis through associating with mitotic spindle and midbody.. J. Biol. Chem. 2001;276(8):5821-5828.

32. Hutterer A, Glotzer M, Mishima M. Clustering of centralspindlin is essential for its accumulation to the central spindle and the midbody.. Curr. Biol. 2009;19(23):20432049.

33. Wolfe BA, Takaki T, Petronczki M, Glotzer M. Polo-like kinase 1 directs assembly of the HsCyk-4 RhoGAP/Ect2 RhoGEF complex to initiate cleavage furrow formation.. PLoS Biol. 2009;7(5):e1000110.

34. Goudsmit R et al. Congenital dyserythropoietic anaemia, type 3.. Br. J. Haematol. 1972;23(1):97-105.

35. McCluggage WG, Hull D, Mayne E, Bharucha H, Wickramasinghe SN. Malignant lymphoma in congenital dyserythropoietic anaemia type III.. J. Clin. Pathol. 1996;49(7):599-602.

36. Zhuravlev $\mathrm{Y}$ et al. CYK-4 regulates Rac, but not Rho, during cytokinesis.. Mol. Biol. Cell 2017;28(9):1258-1270.

37. Basant A, Glotzer M. Spatiotemporal Regulation of RhoA during Cytokinesis.. Curr. Biol. 2018;28(9):R570-R580. 
medRxiv preprint doi: https://doi.org/10.1101/2021.04.07.21254990; this version posted April 10, 2021. The copyright holder for this preprint (which was not certified by peer review) is the author/funder, who has granted medRxiv a license to display the preprint in perpetuity.

It is made available under a CC-BY-NC-ND 4.0 International license .

368 38. Miller AL, Bement WM. Regulation of cytokinesis by Rho GTPase flux.. Nat. Cell 369 Biol. 2009;11(1):71-77.

370 39. Verbrugghe KJC, White JG. SPD-1 is required for the formation of the spindle 371 midzone but is not essential for the completion of cytokinesis in C. elegans embryos..

372 Curr. Biol. 2004;14(19):1755-1760.

373 40. Adriaans IE, Basant A, Ponsioen B, Glotzer M, Lens SMA. PLK1 plays dual roles in 374 centralspindlin regulation during cytokinesis.. J. Cell Biol. 2019;218(4):1250-1264.

375 41. Khajuria RK et al. Ribosome levels selectively regulate translation and lineage 376 commitment in human hematopoiesis.. Cell 2018;173(1):90-103.e19.

377 42. Capalbo $L$ et al. The midbody interactome reveals unexpected roles for PP1

378 phosphatases in cytokinesis.. Nat. Commun. 2019;10(1):4513. 